\title{
ACTIVITY OF PHOSPHORUS OF SYNTHETIC Fe-K-P COMPOUNDS IN SUPERPHOSPHATE FERTILIZERS AS AFFECTED BY pH AND IONIC STRENGTH ${ }^{(1)}$
}

\author{
Luís Ignácio Prochnow ${ }^{(2)}$, Gustavo Marques Biasioli ${ }^{(2)}$, Arnaldo \\ Antonio Rodella ${ }^{(2)}$, Sérgio Luís de Jesus ${ }^{(2,3)}$, Célia Regina Montes ${ }^{(2,3)} \&$ \\ Luís Reynaldo Ferracciú Alleoni ${ }^{(2)}$
}

\begin{abstract}
SUMMARY
The concentration of orthophosphate ions released from Fe-K-P compounds $\left(\mathrm{Fe}_{3} \mathrm{KH}_{8}\left(\mathrm{PO}_{4}\right)_{6} \cdot 6 \mathrm{H}_{2} \mathrm{O}\right.$ and $\left.\mathrm{Fe}_{3} \mathrm{KH}_{14}\left(\mathrm{PO}_{4}\right)_{8} .4 \mathrm{H}_{2} \mathrm{O}\right)$ present in superphosphates increases with $\mathrm{pH}$, which initially suggests that the agronomic effectiveness of $\mathrm{P}$ fertilizers containing high amounts of these compounds would also increase with soil pH but studies considering activity, instead of concentration, are necessary. With this purpose, both compounds were synthesized under laboratory conditions, characterized by elemental chemical analysis, optical microscopy, $\mathrm{X}$ ray diffractometry, scanning electron microscopy (SEM) and energy dispersive spectroscopy (EDS), and used in a solubility study. Solutions of $0.01,0.05$ and $0.1 \mathrm{~mol} \mathrm{~L}^{-1} \mathrm{NaCl}$ with $\mathrm{pH}$ adjusted to 3.0, 4.0, 5.0, 5.5, 6.0, 6.5, 7.0 and 7.5 were prepared for the solubility study of H8-syn, H14-syn and a phosphate rock (PR) from Brazil. The orthophosphate activity as $\mathrm{H}_{2} \mathrm{PO}_{4}^{-}$and $\mathrm{HPO}_{4}{ }^{2-}$ was calculated in each situation as related to $\mathrm{pH}$ and ionic strength using software MINTEQ. The remaining precipitates after equilibrium were chemically analyzed and subjected to $\mathrm{X}$ ray, SEM and EDS. Results of chemical analysis and instrumental techniques confirmed the preparation method. The activity of orthophosphate ions of both compounds tended to decrease under increasing $\mathrm{pH}$ and/or ionic strength of the solution, which in turn suggests that an increase in the solution $\mathrm{pH}$ does not necessarily promote an increase in the $\mathbf{P}$ bioavailability for plant uptake. This can be important when evaluating agronomic data of $P$ fertilizers with high contents of these two Fe-K-P compounds.
\end{abstract}

Index terms: Phosphate fertilizers, cationic impurities, phosphorus activity, phosphorus bioavailability.

\footnotetext{
${ }^{(1)}$ Research Project conducted with financial support from the Research Foundation for the State of São Paulo (FAPESP). Part of the thesis submitted for the degree of Master of Soil and Plant Nutrition, USP/ESALQ, by the second author. Received for publication in January of 2005 and aproved in April of 2006.

(2) Soil Science and Plant Nutrition Department. CEP 13418-900 Piracicaba (SP) Brazil. E-mail: liprochn@esalq.usp.br

(3) NUPEGEL. CEP 13418-900 Piracicaba (SP) Brazil.
} 


\title{
RESUMO: EFEITO DO pH E DA FORÇA IÔNICA NA ATIVIDADE DE FÓSFORO ORIUNDO DE COMPOSTOS SINTETICOS DO TIPO Fe-K-P DE SUPERFOSFATOS
}

\begin{abstract}
O aumento do $\mathrm{pH}$ da concentração de ions ortofosfatos liberados de compostos do tipo $\mathrm{Fe}$ $\mathrm{K}-\mathrm{P}\left(\mathrm{Fe}_{3} \mathrm{KH}_{8}\left(\mathrm{PO}_{4}\right)_{6} \cdot 6 \mathrm{H}_{2} \mathrm{O}\right.$ e $\left.\mathrm{Fe}_{3} \mathrm{KH}_{14}\left(\mathrm{PO}_{4}\right)_{8} \cdot 4 \mathrm{H}_{2} \mathrm{O}\right)$, presentes em superfosfatos, evidenciam, inicialmente, que a eficiência agronômica de fertilizantes fosfatados, com elevadas quantidades destes, poderiam aumentar com o $\mathrm{pH}$ do solo; todavia, estudos que considerem atividades, em vez de concentração, são necessários. Com este propósito, ambos os compostos foram preparados em condições de laboratório (H8-sin e H14-sin), caracterizados por análise química elementar, microscopia óptica, raios $X$, microscopia eletrônica de varredura (MEV) e espectrometria de energia dispersiva (EDS), e utilizados em um estudo de solubilidade. Soluções de NaCl, nas concentrações de 0,01, 0,05 e 0,1 $\mathrm{mol} \mathrm{L}^{-1} \mathrm{com}$ o $\mathrm{pH}$ ajustado de 3 a 7,5, foram utilizadas no estudo de solubilidade envolvendo o H8-sin, H14-sin e um fosfato de rocha apatítico do Brasil. O programa MINTEQ foi utilizado para calcular a atividade dos ortofosfatos $\mathrm{H}_{2} \mathrm{PO}_{4}$ e $\mathrm{HPO}_{4}{ }^{2-}$ em cada situação de $\mathrm{pH}$ e força iônica. O tipo de precipitado remanescente, quando atingido o equilíbrio, foi submetido à análise química elementar, raios $X, M E V$ e EDS. As análises confirmaram que os métodos de preparo foram adequados para ambos os compostos. $A$ atividade dos íns ortofosfatos oriundos da reação de hidrólise do H8-sin e H14-sin tendeu a diminuir com o aumento do $\mathrm{pHe}$, ou, a força iônica da solução, o que mostra que um aumento da concentração em solução não necessariamente significa um aumento da biodisponibilidade de $P$ às plantas. Estes dados poderão ser importantes para compreender a eficiência de fertilizantes fosfatados que contêm elevadas quantidades desses compostos.
\end{abstract}

Termos de indexação: fertilizantes fosfatados, impurezas catiônicas, atividade de fósforo, biodisponibilidade de fósforo.

\section{INTRODUCTION}

As anticipated by Catchcart (1980), levels of waterinsoluble compounds are on the rise in acidulated phosphate fertilizers (APF) as the industry is being forced to use lower-grade phosphate rock (PR). For many phosphate rocks (PR), high amounts of contaminants or even some apatite bounded to contaminants are presently being discarded to adequate the apatite concentrates to the standards set by the legislation of several countries by producing high water-soluble APF (Brazil, 1982; Official Journal of the European Communities, 1975).

In superphosphates, two of the most common water-insoluble compounds are $\mathrm{Fe}_{3} \mathrm{KH}_{8}\left(\mathrm{PO}_{4}\right)_{6} \cdot 6 \mathrm{H}_{2} \mathrm{O}$ (H8) and $\mathrm{Fe}_{3} \mathrm{KH}_{14}\left(\mathrm{PO}_{4}\right)_{8} .4 \mathrm{H}_{2} \mathrm{O}$ (H14) (Lehr et al., 1967; Frazier et al., 1991; Prochnow et al., 2003b). $\mathrm{H} 8$ preferentially forms at $\mathrm{P}_{2} \mathrm{O}_{5}$ concentrations below $39 \%$ and $\mathrm{H} 14$ forms at $\mathrm{P}_{2} \mathrm{O}_{5}$ concentrations in the range of 39 to $70 \%$ (Frazier et al., 1989). As a consequence, $\mathrm{H} 8$ and $\mathrm{H} 14$ generally occur in single and triple superphosphates, respectively.

Some studies were carried out on the agronomic effectiveness of APF with lower water solubility, due to the presence of compounds of the Fe-Al-P type and compared to those specified by legislation (high in water solubility and almost free of Fe-Al-P compounds). Many greenhouse and some field studies suggest that the level of impurities in $\mathrm{APF}$ would have to be increased above current levels before effectiveness would be affected (Mullins \& Sikora, 1992, 1995; Sikora et al., 1989; Prochnow et al., 2003a, 2003b). Better use of low-grade PR is possible by producing agronomically effective $\mathrm{APF}$ varying in water solubility (Lehr, 1980).

Prochnow et al. (2003a) showed that more P, as measured in terms of orthophosphate concentration in solution (Murphy \& Riley, 1962), was released from both compounds as $\mathrm{pH}$ increased in the $0.01 \mathrm{M} \mathrm{KCl}$ solution (pH 3.0-7.5) and that more $\mathrm{P}$ was released from $\mathrm{H} 14$ than $\mathrm{H} 8$, both synthesized at laboratory conditions ( $49 \%$ of the total $\mathrm{P}$ at $\mathrm{pH} 6.0$ was released from $\mathrm{H} 14$ versus only $11 \%$ from H8). The authors initially suggest that the agronomic effectiveness of $\mathrm{P}$ fertilizers containing high amounts of $\mathrm{H} 8$ and/or $\mathrm{H} 14$ would increase as soil $\mathrm{pH}$ increases, but further studies considering activity, which could represent the bioavailability of chemical species to plants more adequately, are required. In the soil system, the great majority of ions are free or interacting with other ions and molecules, thus forming ion pairs (Sposito, 1994). Around 100 to 200 soluble complexes can be found (Sposito, 1984) and activity is important to understand the bioavailabity of chemical elements to plants. As an example, Pavan \& Bingham (1982) showed that activity was closer related to Al bioavailability to coffee seedlings than its concentration. Likewise, orthophosphate activity in solution could represent bioavailability better than the concentration. This information would be relevant with a view to gain insights on agronomic data of APF with high $\mathrm{H} 8$ and, 
or, H14 contents in different conditions of soil solution. This study aimed to gather information regarding this issue.

\section{MATERIAL AND METHODS}

The H8 and H14 compounds were synthesized based on information provided by Lehr et al. (1967) and Frazier et al. (1991) and were identified as H8syn and H-14 syn, respectively. During the synthesis process, the crystal morphology (hexagonal rods and pseudohexagonal plates for H8-syn and H14-syn, respectively) was monitored by optical microscopy, using a Carl Zeiss Model Axioskop polarizing light microscope. The yield was 206 and $80 \mathrm{~g}$ of H8-syn and H14-syn, respectively. Both compounds were characterized by elemental chemical analysis, optical microscopy, X ray diffractometry, scanning electron microscopy (SEM) and energy dispersive spectroscopy (EDS).

Samples of the two compounds were analyzed for free water, water of hydration and total P, Fe, K, S$\mathrm{SO}_{4}$ and soluble $\mathrm{P}$ contents in neutral ammonium citrate (NAC). The analytical procedure for total $\mathrm{P}$, Fe and $\mathrm{K}$ involved the digestion of a $1.00 \mathrm{~g}$ sample, using a mixture of concentrated $\mathrm{HClO}_{4}: \mathrm{HNO}_{3}$ at 2:1 volume ratio, followed by filtration through Whatman $\mathrm{N}^{\circ} 42$ filter paper. The filtrate was collected in a $500 \mathrm{~mL}$ volumetric flask and diluted to volume with distilled water. The total $\mathrm{P}$ concentration was determined by the molybdovanadophosphate procedure [Association of Official Analytical Chemists (AOAC), 1999]. The Fe concentration was determined using a Perkin-Elmer Model 560 atomic absorption spectrophotometer, and K using a Corning Model 400 flame spectrometer. The AOAC procedure (1999) was used to determine $\mathrm{S}_{-} \mathrm{SO}_{4}$ and soluble $\mathrm{P}$ in NAC and in water. The free water was determined by the vacuum desiccation method (AOAC, 1999). After removing the free water, the water of hydration was determined by distillation, according to the n-amyl alcohol method (Duncan \& Brabson, 1969). Total water was obtained by the summation of free water and water of hydration.

The two Fe-K-P compounds in the mother liquor, after being washed with water and dried with acetone, were examined using the Carl Zeiss Model Axioskop polarizing light microscope, to obtain the morphological and optical data, including crystal system, habit, and refractive indices. Refractive indices were measured by the Becke line method (Wahlstrom, 1979) with certified refractive index oils.

Samples of $20 \mathrm{~g}$ of H8-syn and H14-syn were prepared for X ray analysis by grinding with $10 \mathrm{~mL}$ Freon for 7 min in an impact grinder. The samples were step-scanned with a Philips Model X'Pert PW $3710 \mathrm{X}$ ray powder diffractometer from 3.0 to 70.0 degrees 2-Theta, at a step size of 0.04 degree 2Theta and a dwell-time of three seconds, with $\mathrm{Cu}$ radiation produced at a power setting of $40 \mathrm{kV}$ and $40 \mathrm{~mA}$. The data were analyzed using the powder diffraction file (PDF) database [International Center for Diffraction Data (ICDD), 1999], to which XRD patterns for Fe-Al-P compounds were added, as described by Frazier et al. (1991).

A portion of H8-syn and H14-syn was placed on individual sample stubs using double-faced scotch tape coated with carbon. The samples were scanned in a Jeol Model JSM 5600LV SEM with accelerating voltage from 15 to $30 \mathrm{kV}$ using a Noran/Voyager EDS operating in a range of 0 to $10 \mathrm{kV}$. The scanning procedure targeted structures with defined micromorphology in the sample.

Solutions of $0.01,0.05$ and $0.1 \mathrm{~mol} \mathrm{~L}^{-1} \mathrm{NaCl}$ with $\mathrm{pH}$ adjusted to $3.0,4.0,5.0,5.5,6.0,6.5,7.0$ and 7.5 were used in the solubility study of H8-syn, H14-syn and a Catalão $\mathrm{PR}\left(13 \% \mathrm{P}_{2} \mathrm{O}_{5}\right)$ from Brazil containing, besides the apatite, silicate and oxide minerals. The solutions were chosen based on the concentrations and $\mathrm{pH}$ of regular agricultural soils. A $50 \mathrm{~mL}$ volume of each of these solutions was added to a plastic snap cap vial in which a $166 \mathrm{mg}$ sample of each $\mathrm{P}$ source was also added. The samples were shaken continuously until the solution $\mathrm{pH}$ reached the equilibrium near the target $\mathrm{pH}$ values. The $\mathrm{pH}$ was adjusted to the target $\mathrm{pH}$ every $24 \mathrm{~h}$ by adding drops of $0.01,0.1$ or $1.0 \mathrm{~mol} \mathrm{~L}^{-1}$ solution of either $\mathrm{KOH}$ or $\mathrm{HCl}$.

After reaching the equilibrium, the samples were filtered through Whatman No 42 filter paper, and the $\mathrm{P}, \mathrm{Fe}, \mathrm{K}, \mathrm{S}-\mathrm{SO}_{4}, \mathrm{Na}$ and $\mathrm{Cl}$ concentration was measured in the Murphy and Riley (1962) solution, by atomic absorption, flame spectroscopy, by the gravimetric method of barium sulfate (AOAC, 1999), flame spectroscopy, and titration with $\mathrm{AgNO}_{3}$ [Laboratório nacional de referência vegetal (LANARV), 1983], respectively. Phosphorus released from each $\mathrm{P}$ source was expressed as the percentage of the added P amounts. MINTEQ (Allison et al., 1991) was used to calculate the separate activity of the orthophosphates $\mathrm{H}_{2} \mathrm{PO}_{4}^{-}$and $\mathrm{HPO}_{4}^{2-}$ in each situation, as related to $\mathrm{pH}$ and ionic strength. The activities of both orthophosphate species were summed up and used in discussions once both forms are bioavailable to plants.

To gather information on the type of remaining precipitates in the filter paper, a larger batch $(4.98 \mathrm{~g}$ of the compound in $1.5 \mathrm{~L}$ ) of both compounds was prepared with equilibrium solutions reaching, approximately, $\mathrm{pH} 5.0$ and 7.0. The remaining precipitates in the filter paper were chemically analyzed and submitted to X ray, MEV and EDS, as described above.

\section{RESULTS AND DISCUSSION}

Concentration of total $\mathrm{P}, \mathrm{Fe}, \mathrm{K}$ and water of hydration of H8-syn and H14-syn (Table 1) were very 
close to those expected for $\mathrm{H} 8$ and $\mathrm{H} 14$, considering the chemical composition of their empirical formula. The amounts of $\mathrm{S}_{-} \mathrm{SO}_{4}$ in H8-syn (1.0 \%) and H14syn $(0.1 \%)$ were accounted as remaining $\mathrm{Fe}_{2}\left(\mathrm{SO}_{4}\right)_{3} \cdot 7 \mathrm{H}_{2} \mathrm{O}$ (one of the initial reagents) in the materials. The high available $\mathrm{P}\left(\mathrm{NAC}+\mathrm{H}_{2} \mathrm{O}\right)$, as related to the total content of $\mathrm{P}(99$ and $97 \%$ for $\mathrm{H} 8$ syn and H14-syn, respectively) is mainly due to the solubility in NAC, not in water. This high solubility in NAC does not necessarily mean a high $\mathrm{P}$ bioavailability for plant uptake. As explained by Prochnow et al. (2003a), two factors interact when high $\mathrm{P}$ amounts are extracted by NAC from compounds of the Fe-P type: (1) citrate is a chelating ligand that can complex Fe with a high formation constant (higher than $\mathrm{Ca}-\mathrm{P}$ or $\mathrm{Al}-\mathrm{P}$ ), and (2) Fe-P minerals are more soluble in high $\mathrm{pH}$ solutions. Therefore, the amounts extracted by NAC can be higher than the amounts actually bioavailable for plant uptake.

The optical data of both compounds were found to be essentially homogeneous and identical to $\mathrm{H} 8$ (hexagonal rods; uniaxial $(+) ; \omega=1.595, \varepsilon=1.601$ ) and H14 (orthorhombic-hexagonal shaped plates; biaxial (-); $\alpha=1.556, \beta=1.600, \gamma=1.606)$. In terms of peak location and intensity the $\mathrm{X}$ ray powder diffraction patterns obtained for the H8-syn and H14syn samples agreed very well with the $\mathrm{X}$ ray patterns for these compounds taken from the Powder Diffraction File (PDF) (ICDD, 1999) or with those cited by Frazier et al. (1991) (Figure 1). The SEM photomicrographs of specific areas of crystals in the H8-syn and H14syn samples are shown in Figure 2. The morphology of the compounds which identified hexagonal rod crystals for H8-syn and pseudo-hexagonal plates for H14-syn was in line with the morphology suggested by Frazier et al. (1989). Our EDS analysis of specific
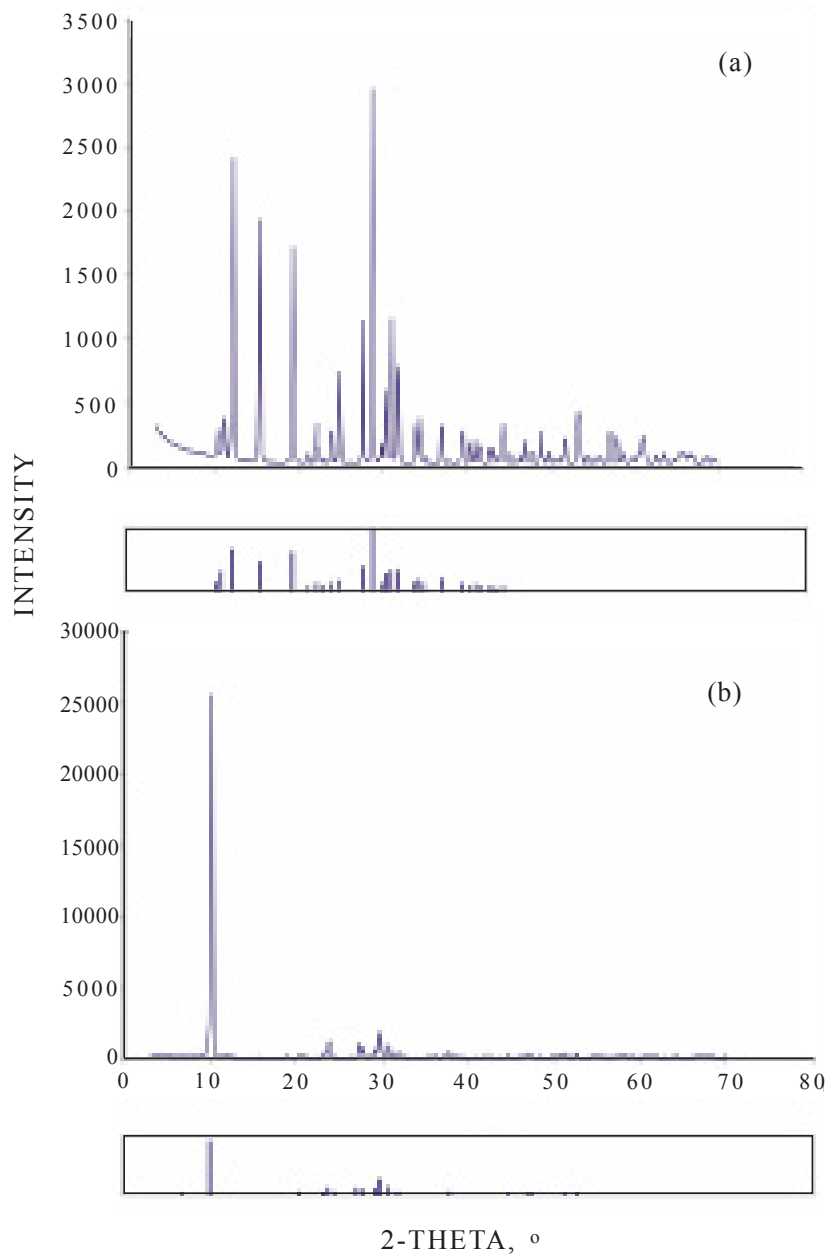

Figure 1. X ray diffractogram and powder diffraction file (PDF) data of the compounds H8-syn (A) and H14-syn (B).

Table 1. Elemental chemical composition - theoretical and obtained by analytical methods - for the compounds $\mathrm{H} 8$ and $\mathrm{H} 14$

\begin{tabular}{|c|c|c|c|c|}
\hline \multirow{2}{*}{ Determination } & \multicolumn{2}{|c|}{ H8 } & \multicolumn{2}{|c|}{ H14 } \\
\hline & Theoretical & Analytical & Theoretical & Analytical \\
\hline & & 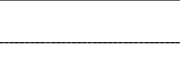 & 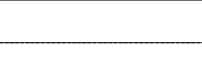 & $\underline{-}$ \\
\hline Total P & 20.8 & 20.0 & 23.6 & 23.3 \\
\hline NAC Soluble P & - & 19.8 & - & 21.8 \\
\hline Water Soluble P (WSP) & - & 0.03 & - & 0.8 \\
\hline Available $\mathrm{P}\left(\mathrm{NAC}+\mathrm{H}_{2} \mathrm{O}\right)$ & - & 19.8 & - & 22.6 \\
\hline$(\mathrm{WSP} /$ Available P) $* 100$ & - & 0.2 & - & 3.5 \\
\hline $\mathrm{Fe}$ & 18.8 & 17.4 & 16.0 & 14.3 \\
\hline $\mathrm{K}$ & 4.3 & 4.7 & 3.7 & 3.9 \\
\hline $\mathrm{S}-\mathrm{SO}_{4}$ & - & 1.0 & - & 0.1 \\
\hline Free water & - & 0.3 & - & 0.1 \\
\hline Water of Hydration & 12.1 & 11.9 & 6.8 & 7.3 \\
\hline Total water & - & 12.2 & - & 7.4 \\
\hline
\end{tabular}


areas of both crystals suggests that the compounds consisted basically of Fe, K and P (data not shown). No other morphological structures were found in the samples of H8-syn and H14-syn. Results of chemical analysis (Table 1), optical microscopy, X ray diffractrometry (Figure 1), compound morphology (Figure 2), and EDS analysis of areas of the crystals confirmed that the method of preparation was successful and that H8-syn and H14-syn can be considered as $\mathrm{Fe}_{3} \mathrm{KH}_{8}\left(\mathrm{PO}_{4}\right)_{6} \cdot 6 \mathrm{H}_{2} \mathrm{O}$ and $\mathrm{Fe}_{3} \mathrm{KH}_{14}\left(\mathrm{PO}_{4}\right)_{8} \cdot 4 \mathrm{H}_{2} \mathrm{O}$, respectively, with no contaminants.

Figure 3 shows the amount of $\mathrm{P}$ released by the $\mathrm{P}$ materials as a function of the $\mathrm{pH}$ at equilibrium of the $0.01 \mathrm{~mol} \mathrm{~L}^{-1} \mathrm{NaCl}$ solution. Similar trends were observed for the other two solutions, i.e., 0.05 and $0.1 \mathrm{~mol} \mathrm{~L}^{-1} \mathrm{NaCl}$. The amounts of released $\mathrm{P}$ when Catalão PR was used tended to decrease with increasing $\mathrm{pH}$. This is consistent with solubility studies on other PR sources and agronomic evaluation of apatitic PR (Engelstad et al., 1974; Chien et al., 1975). For the Fe-P compounds the trend was opposite (Figures 3 and 4), with a slight increase in the amounts of $\mathrm{P}$ released with increasing $\mathrm{pH}$. Also, the amount of $\mathrm{P}$ released from H14-syn was much higher (a)

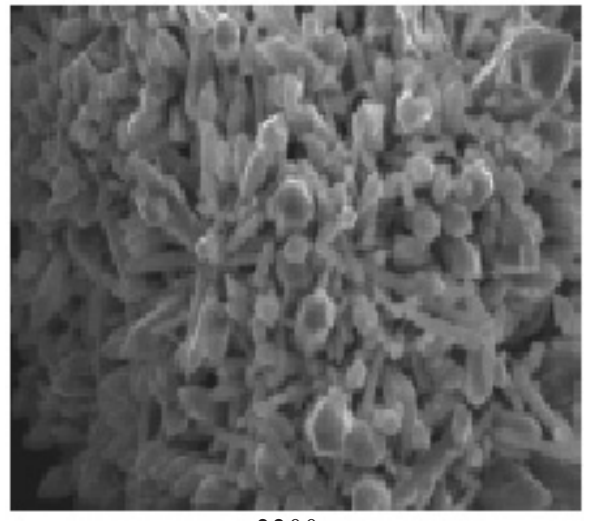

x 2200

(b)

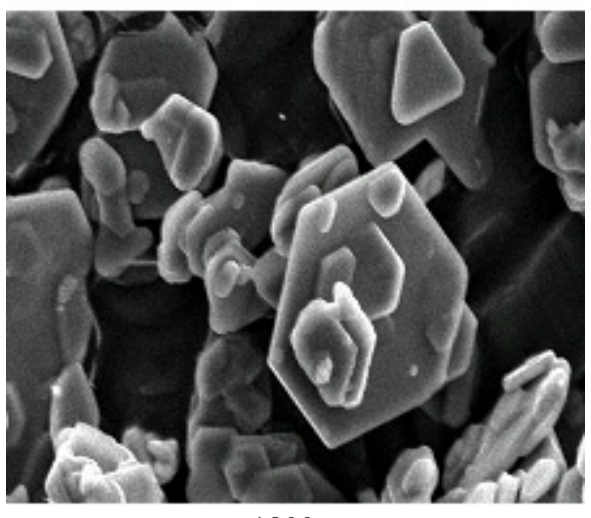

x 1800

Figure 2. Scanning electron microscopy (SEM) photomicrograph of sub sample of the H8-syn (A) showing hexagonal rod crystals and of H14syn (B) showing pseudo-hexagonal plates. than from H8-syn. Similar results were observed by Prochnow et al. (2003a), who suggested that H14 would be a more effective $\mathrm{P}$ source for plants than $\mathrm{H} 8$ and that both Fe-K-P compounds could be agronomically more effective in high $\mathrm{pH}$ soils.

For H8-syn there was a clear trend towards a higher $\mathrm{P}$ release when using $0.01 \mathrm{~mol} \mathrm{~L}^{-1} \mathrm{NaCl}$, compared to the other two $\mathrm{NaCl}$ concentrations (Figure 4). This should be related to higher hydrolysis of this compound at lower ionic strength. The same trend was not observed for the other two P materials, most likely due to the higher amounts of $\mathrm{P}$ released.

The activity of $\mathrm{H}_{2} \mathrm{PO}_{4}{ }^{-}+\mathrm{HPO}_{4}{ }^{2-}$ followed some of the trends discussed for concentration, i.e., (1) decrease in activity with increasing $\mathrm{pH}$ for Catalão $\mathrm{PR}$ and (2) a much higher activity when using H14-syn, compared to H8-syn and PR (data not shown). For H14-syn, the effect of ionic strength was evident for activity at $\mathrm{pH}>4$, as shown in figure 5 (activity above pH 4: $0.01>0.05>0.1 \mathrm{~mol} \mathrm{~L}^{-1}$ of $\mathrm{NaCl}$ ). For the $\mathrm{NaCl}$ solutions of 0.05 and $0.1 \mathrm{~mol} \mathrm{~L}^{-1}$ the activity tended to increase up to around $\mathrm{pH} 5$ and decrease afterwards. For the $\mathrm{NaCl} 0.01 \mathrm{~mol} \mathrm{~L}^{-1}$, the trend was the same with a flex point at around $\mathrm{pH}$. The

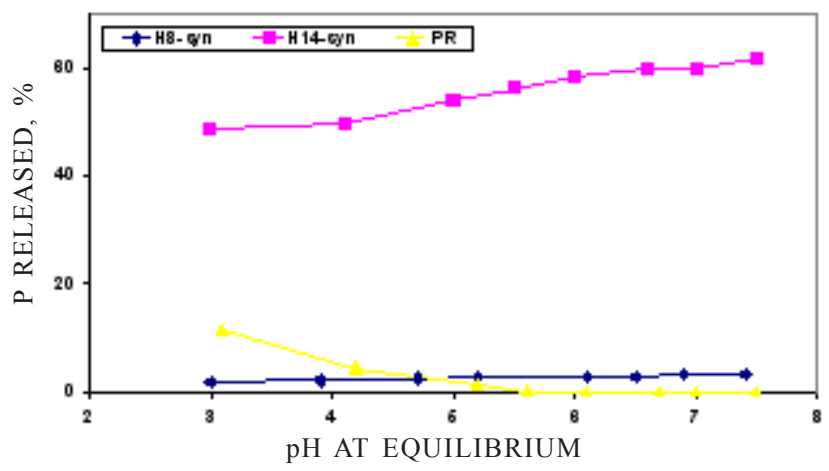

Figure 3. P released (\%) from the reaction of H8-syn, H14-syn and Catalão PR as a function of the $\mathrm{pH}$ at equilibrium of a $0.01 \mathrm{~mol} \mathrm{~L}^{-1} \mathrm{NaCl}$ solution.

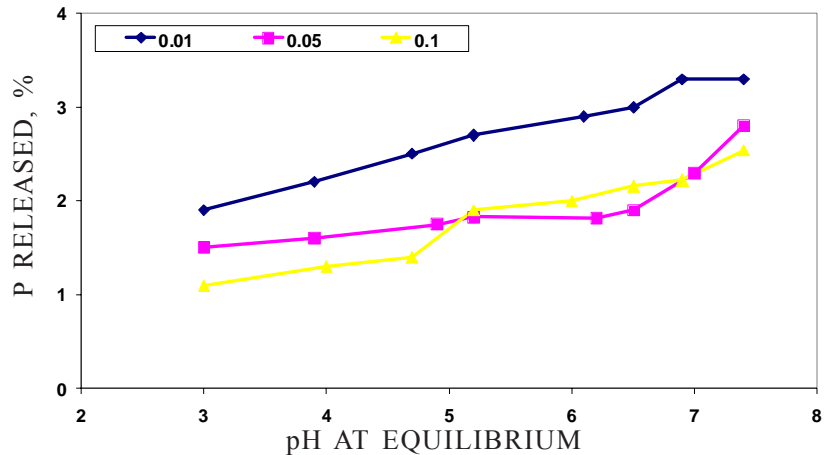

Figure 4. $P$ released (\%) from the hydrolysis reaction of H8-syn as a function of $\mathrm{pH}$ at equilibrium of $\mathrm{NaCl}$ solutions with concentrations of $0.01,0.05$ and $0.1 \mathrm{~mol} \mathrm{~L}^{-1}$. 
increase in the relative amount of the ion pair $\mathrm{NaHPO}_{4}^{-}$(Table 2) should be the explanation for the decrease in the activity of the orthophosphate ions after a certain $\mathrm{pH}$. Results are in accordance with Sposito (1989), who mentioned that the activity of an ion tends to decrease with an increased ionic strength $\left(\log f_{\mathrm{i}}=-A z_{\mathrm{i}}^{2} \sqrt{\mu} ; a_{\mathrm{i}}=c_{\mathrm{i}} f_{\mathrm{i}}\right.$, where: $f_{i}=$ activity coefficient, $\mathrm{A}=$ parameter related to the dieletrical constant, $\mathrm{z}_{i}=$ charge of the ion, ì = ionic strength, $a_{i}$ $=$ ion activity, $c_{i}=$ ion concentration). According to the formulas it is possible to infer that a higher $\mu$ leads to higher negative $\log$ of $f_{i}$, or in other words, lower values of $f_{i}$, which will result to lower activity values. Consequently, the activity of the orthophosphate ions from the H8-syn and H14-syn

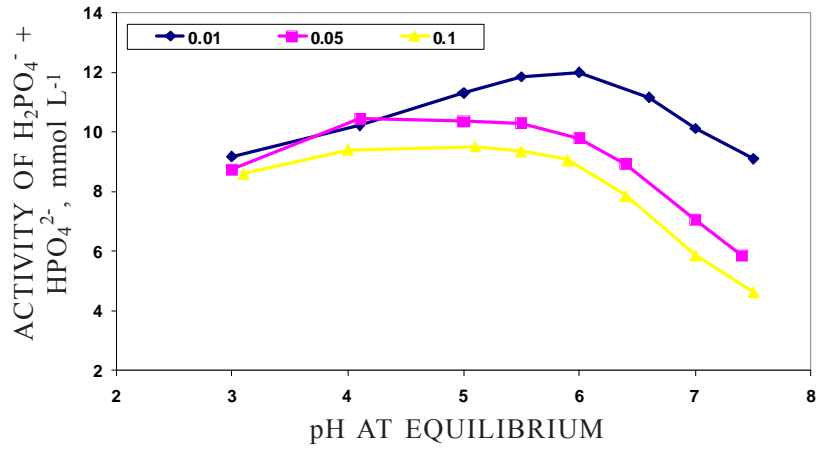

Figure 5. Activity of $\mathrm{H}_{2} \mathrm{PO}^{-}+\mathrm{HPO}_{4}{ }^{2-}$ from the hydrolysis reaction of $\mathrm{H} 14$-syn as a function of pH at equilibrium of $\mathrm{NaCl}$ solutions with concentrations of $0.01,0.05$ and $0.1 \mathrm{~mol} \mathrm{~L}^{-1}$.

Table 2. Relative distribution of chemical species of $\mathrm{P}$ present in solution from the hydrolysis of the H14$\mathrm{syn}$, as a function of $\mathrm{pH}$ and $\mathrm{NaCl}$ concentration

\begin{tabular}{|c|c|c|c|c|c|c|c|c|}
\hline \multirow{3}{*}{ Chemical specie } & \multicolumn{8}{|c|}{ NaCl $0.01 \mathrm{~mol} \mathrm{~L}^{-1}$} \\
\hline & \multicolumn{8}{|c|}{$\mathbf{p H}$} \\
\hline & 3 & 4.1 & 5.0 & 5.5 & 6.0 & 6.6 & 7.0 & 7.5 \\
\hline $\mathrm{HPO}_{4}{ }^{2-}$ & - & 0.1 & 0.8 & 2.6 & 7.5 & 23.6 & 41.1 & 62.1 \\
\hline $\mathrm{H}_{2} \mathrm{PO}_{4}$ & 86.0 & 95.2 & 95.2 & 93.3 & 87.7 & 68.6 & 47.5 & 22.7 \\
\hline $\mathrm{H}_{3} \mathrm{PO}_{4}$ & 10.9 & 1.0 & 0.1 & - & - & - & & - \\
\hline $\mathrm{NaHPO}_{4}^{-}$ & - & - & 0.1 & 0.4 & 1.3 & 4.6 & 8.7 & 13.4 \\
\hline $\mathrm{NaH}_{2} \mathrm{PO}_{4} \cdot(\mathrm{aq})$ & 2.7 & 3.4 & 3.4 & 3.3 & 3.1 & 2.8 & 2.1 & 1.0 \\
\hline $\mathrm{Na}_{2} \mathrm{HPO}_{4}(\mathrm{aq})$ & - & - & - & - & - & 0.1 & 0.2 & 0.2 \\
\hline $\mathrm{KHPO}_{4}$ & - & - & - & - & - & 0.2 & 0.4 & 0.5 \\
\hline $\mathrm{KH}_{2} \mathrm{PO}_{4}(\mathrm{aq})$ & 0.3 & 0.3 & 0.3 & 0.3 & 0.2 & 0.2 & 0.1 & 0.1 \\
\hline $\mathrm{FeHPO}_{4}{ }^{+}$ & 0.1 & - & - & - & - & - & - & - \\
\hline \multirow[t]{4}{*}{$\mathrm{FeH}_{2} \mathrm{PO}_{4}{ }^{2+}$} & - & - & - & - & - & - & - & - \\
\hline & \multicolumn{8}{|c|}{ NaCl $0.05 \mathrm{~mol} \mathrm{~L}^{-1}$} \\
\hline & \multicolumn{8}{|c|}{$\mathbf{p H}$} \\
\hline & 3.0 & 4.1 & 5.0 & 5.5 & 6.0 & 6.4 & 7.0 & 7.4 \\
\hline $\mathrm{HPO}_{4}{ }^{2-}$ & - & 0.1 & 1.0 & 3.2 & 9.2 & 19.1 & 42.4 & 55.3 \\
\hline $\mathrm{H}_{2} \mathrm{PO}_{4}^{-}$ & 83.1 & 90.4 & 90.3 & 87.4 & 79.9 & 66.4 & 37.0 & 19.2 \\
\hline $\mathrm{H}_{3} \mathrm{PO}_{4}$ & 9.5 & 0.8 & 0.1 & - & - & - & - & - \\
\hline $\mathrm{NaHPO}_{4}$ & - & 0.1 & 0.4 & 1.2 & 3.3 & 7.4 & 16.2 & 22.3 \\
\hline $\mathrm{NaH}_{2} \mathrm{PO}_{4} \cdot(\mathrm{aq})$ & 7.0 & 8.2 & 7.9 & 7.9 & 7.2 & 6.4 & 3.5 & 1.9 \\
\hline $\mathrm{Na}_{2} \mathrm{HPO}_{4}(\mathrm{aq})$ & - & - & - & - & 0.1 & 0.3 & 0.6 & 0.8 \\
\hline $\mathrm{KHPO}_{4}$ & - & - & - & - & 0.1 & 0.2 & 0.3 & 0.4 \\
\hline $\mathrm{KH}_{2} \mathrm{PO}_{4}(\mathrm{aq})$ & 0.3 & 0.4 & 0.3 & 0.3 & 0.3 & 0.2 & 0.1 & 0.1 \\
\hline $\mathrm{FeHPO}_{4}^{+}$ & 0.1 & - & - & - & - & - & - & - \\
\hline \multirow[t]{4}{*}{$\mathrm{FeH}_{2} \mathrm{PO}_{4}{ }^{2+}$} & - & - & - & - & - & - & - & - \\
\hline & \multicolumn{8}{|c|}{$\mathrm{NaCl} 0.01 \mathrm{~mol} \mathrm{~L}^{-1}$} \\
\hline & \multicolumn{8}{|c|}{$\mathbf{p H}$} \\
\hline & 3.1 & 4.0 & 5.1 & 5.5 & 5.9 & 6.4 & 7.0 & 7.5 \\
\hline $\mathrm{HPO}_{4}{ }^{2-}$ & - & 0.1 & 1.5 & 3.5 & 8.2 & 20.5 & 42.6 & 56.7 \\
\hline $\mathrm{H}_{2} \mathrm{PO}_{4}$ & 82.4 & 87.7 & 86.5 & 83.8 & 77.9 & 61.2 & 32.0 & 13.5 \\
\hline $\mathrm{H}_{3} \mathrm{PO}_{4}$ & 7.0 & 0.9 & 0.1 & - & - & - & - & - \\
\hline $\mathrm{NaHPO}_{4}$ & - & 0.1 & 0.7 & 1.7 & 3.8 & 9.7 & 20.0 & 26.4 \\
\hline $\mathrm{NaH}_{2} \mathrm{PO}_{4}$ (aq) & 10.2 & 10.9 & 11.0 & 10.6 & 9.6 & 7.9 & 4.1 & 1.7 \\
\hline $\mathrm{Na}_{2} \mathrm{HPO}_{4}(\mathrm{aq})$ & - & - & - & 0.1 & 0.2 & 0.5 & 1.0 & 1.3 \\
\hline $\mathrm{KHPO}_{4}$ & - & - & - & - & 0.1 & 0.2 & 0.3 & 0.4 \\
\hline $\mathrm{KH}_{2} \mathrm{PO}_{4}(\mathrm{aq})$ & 0.3 & 0.3 & 0.3 & 0.3 & 0.2 & 0.2 & 0.1 & - \\
\hline $\mathrm{FeHPO}_{4}{ }^{+}$ & - & - & - & - & - & - & - & - \\
\hline
\end{tabular}

(1) Adapted from results calculated by MINTEQ software (Allison et al., 1991). 
tends to decrease when increasing the $\mathrm{pH}$ and/or the ionic strength of the solution.

The analysis of the residues in the filter paper after reaching the equilibrium $\mathrm{pH}$ suggests the presence of compounds very similar to $\mathrm{H} 8$ and amorphous strengite $\left(\mathrm{FePO}_{4} \cdot \mathrm{nH}_{2} \mathrm{O}\right)$ in $\mathrm{H} 8$-syn and $\mathrm{H} 14$-syn, respectively (Figure 6). This is in accordance with the low hydrolysis of $\mathrm{H} 8$ and the chemical hydrolysis reactions suggested by Prochnow et al. (2003a) for both compounds.

In spite of using a simpler solution system than the soil solution, the information obtained in this study suggests that an increased $\mathrm{P}$ concentration for the hydrolysis of $\mathrm{H} 8$ and $\mathrm{H} 14$, as a function of an increase in the solution $\mathrm{pH}$, does not necessarily lead to an intensified activity and consequently an increase in the biovailability of phosphorus to plants, as suggested by Prochnow et al. (2003a). It can be suggested that

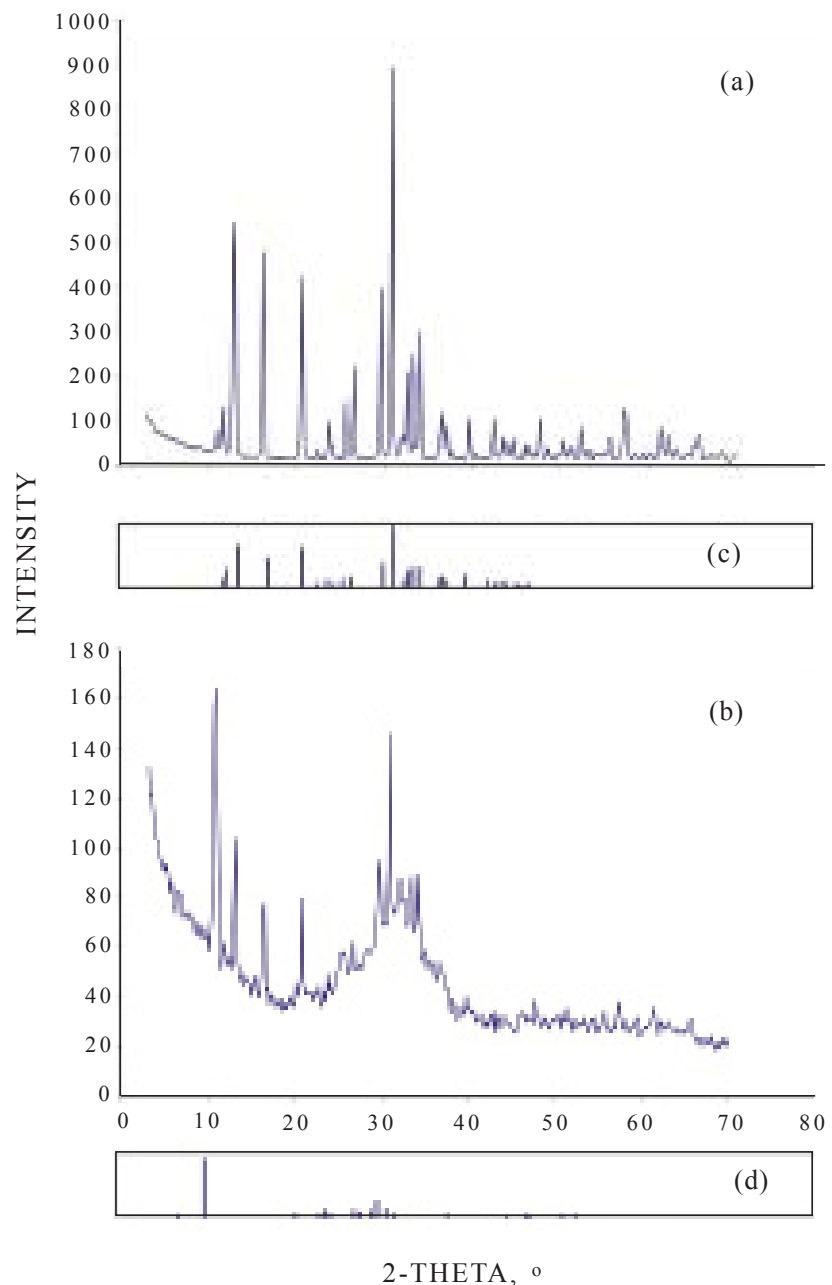

Figure 6. X ray diffractogram and powder diffraction file (PDF) data of the residues remaining in the filter paper after filtration of the solution of $\mathrm{NaCl} 0.01 \mathrm{~mol} \mathrm{~L}^{-1}$ with $\mathrm{pH} 5$ (original compounds: $a=H 8-s y n, b=H 14-s y n$; PDF file: $\mathrm{c}=\mathrm{H} 8, \mathrm{~d}=$ strengite). similar trends would be obtained in the soil system, once the exchangeable cationic concentration tends to increase with the $\mathrm{pH}$. This can be important when agronomic data of $\mathrm{P}$ fertilizers with high contents of both of these Fe-K-P compounds are evaluated. Other studies with real soil solution enriched with Fe-K-P compounds should be carried out to gain further insights into this issue.

\section{CONCLUSION}

Activity of orthophosphate ions derived from the hydrolysis of compounds of the type $\mathrm{Fe}_{3} \mathrm{KH}_{8}\left(\mathrm{PO}_{4}\right)_{6} \cdot 6 \mathrm{H}_{2} \mathrm{O}$ and $\mathrm{Fe}_{3} \mathrm{KH}_{14}\left(\mathrm{PO}_{4}\right)_{8} \cdot 4 \mathrm{H}_{2} \mathrm{O}$ tends to decrease with a higher $\mathrm{pH}$ or ionic strength of the solution. Our results do therefore not confirm the hypothesis that these compounds are more plant available at a higher soil solution $\mathrm{pH}$ where the concentration of released orthophosphate ions is higher.

\section{LITERATURE CITED}

ALLISON, J.D.; BROWN, D.S. \& NOVO-GRADAC, K.J. A geochemical assessment model for environmental systems, version 3.0 user's manual. S.L. U.S. Environmental Protection Agency (EPA/600/3-91/21). 1991. $57 \mathrm{p}$.

ASSOCIATION OF OFFICIAL ANALYTICAL CHEMISTS AOAC. Official methods of analysis. 16.ed. Arlington, Association of Official Analytical Chemists, 1999. v.1

BRASIL. Ministério da Agricultura. Secretaria Nacional de Defesa Agropecuária. Portaria 01 de 04/83; Portaria 03 de 12/06/86. Inspeção e fiscalização da produção e do comércio de fertilizantes, corretivos, inoculantes, estimulantes e biofertilizantes destinados à agricultura; legislação e fiscalização. Brasília, 1982. 88p.

CATHCART, J.B. The phosphate industry of the United States. In: KHASAWNEH, F.E.; SAMPLE E.C. \& KAMPRATH, E.J., eds. The role of phosphorus in agriculture. Madison, American Society of Agronomy, 1980. p.19-42.

CHIEN, S.H.; WIER, D.R. \& BLACK, C.A. Supersaturation phenomena and the formation of fluorapatite in aqueous suspensions of phosphate rock. Soil Sci. Soc. Am. Proc., 39:43-47, 1975.

DUNCAN, R.D. \& BRABSON, J.A.. Determination of free and total water in fertilizers by Karl Fisher titration. J. Assoc. Anal. Chem., 52:1127-1131, 1969.

ENGELSTAD, O.P.; JUGSUJINDA, A. \& DE DATTA, S.K. Response by flooded rice to phosphate rocks varying in citrate solubility. Soil Sci. Soc. Am. Proc., 38:524-529, 1974.

FRAZIER, A.W.; DILLARD, E.F.; THRASHER, R.D.; WAERSTAD, K.R.; HUNTER, S.R., KOHLER, J.J. \& SCHEIB, R.M. Crystallographic properties of fertilizer compounds. Alabama, National Fertilizer Development Center (NFDC), Muscle Shoals, 1991. (NFDC. Bull. Y-217) 
FRAZIER, A.W.; WAERSTAD, K.R.; KIM, Y.R. \& CRIM, B.G. Phase system $\mathrm{Fe}_{2} \mathrm{O}_{3}-\mathrm{K}_{2} \mathrm{O}-\mathrm{P}_{2} \mathrm{O}_{5}-\mathrm{H}_{2} \mathrm{O}$ at $25^{\circ} \mathrm{C}$. Ind. Eng. Chem. Res., 28:225-230, 1989.

INTERNATIONAL CENTRE OF DIFFRACTION DATA ICDD. Powder diffraction file: data sets 1-49 plus 70-86. Release 1999, International Centre for Diffraction Data. Newton Square, 1999. CD ROM

LABORATÓRIO NACIONAL DE REFERÊNCIA VEGETAL LANARV. Análise de corretivos, fertilizantes e inoculantes: métodos oficiais. Brasília, Secretaria Nacional de Defesa Agropecuária, 1983. 104p.

LEHR, J.R. Phosphate raw materials and fertilizers, part I - a look ahead. In: KHASAWNEH, F.E.; SAMPLE, E.C.\& KAMPRATH, E.J. eds. The role of phosphorus in agriculture. Madison, ASA/CSSA/ SSSA, 1980. p.81-120

LEHR, J.R.; BROWN, E.H.; FRAZIER, A.W.; SMITH, J.P. \& THRASHER, R.D. Crystallographic properties of fertilizer compounds. Alabama, National Fertilizer Development Center, Muscle Shoals, 1967. (NFDC Bulletin, 6)

MULLINS G.L. \& SIKORA, F.J. Effect of impurity compounds on the performance of phosphorus fertilizers. In: SIKORA F.J., ed. Future directions for agricultural phosphorus research. Alabama, Muscle Shoals, 1992. p.53-56. (TVA Bulletin Y-224)

MULLINS, G.L. \& SIKORA, F.J. Effect of soil pH on the requirement for water-soluble phosphorus in triple superphosphate fertilizers. Fert. Res., 40:207-214, 1995.

MURPHY, J. \& RILEY, J.P. A modified single solution method for the determination of phosphate in natural water. Anal. Chem., 27:31-36, 1962.
OFFICIAL EUROPEAN COMMUNITIES. Council directive on the approximation of the laws of the member states relating to fertilizers. Offic. J. Eur. Comm., 19:21, 1975.

PAVAN M.A. \& BINGHAM, F.T. Toxicity of aluminum to coffee seedlings grown in nutrient solution. Soil Sci. Soc. Am. J., 46:993-997, 1982.

PROCHNOW, L.I.; CHIEN, S.H.; DILLARD, E.F.; AUSTIN, E.R.; CARMONA, G.; HENAO, J.; SINGH, U. \& TAYLOR, R.W. Synthesis, characterization, and agronomic evaluation of iron phosphate impurities in superphosphates. Soil Sci. Soc. Am. J., 67:1551-1563, 2003a.

PROCHNOW, L.I.; CHIEN, S.H.; TAYLOR, R.W.; CARMONA, G.; HENAO, J. \& DILLARD, E.F. Characterization and agronomic evaluation of single superphosphates varying in iron phosphate impurities. Agron. J., 95:293-302, 2003b.

SIKORA, F.J.; DILLARD, E.F., \& COPELAND, J.P. Chemical characterization and bioavailability of phosphorus in water-insoluble fractions of three mono-ammonium phosphate fertilizers. J. Assoc. Offic. Anal. Chem., 72:852856, 1989.

SPOSITO, G. The chemistry of soils. New York, Oxford University Press, 1989. 277p.

SPOSITO, G. Chemical equilibrium and kinetics in soils. New York, Oxford University Press, 1994. 288p.

SPOSITO, G. The surface chemistry of soils. New York, Oxford University Press, 1984. 288p.

WAHLSTROM, E.E. Optical crystallography. 5.ed. New York, John Wiley \& Sons, 1979. 488p. 